\title{
ENVIRONMENT v. DEVELOPMENT REVISITED: CONTRIBUTIONS OF INDIA'S JUDICIARY TO THE CONFLICT RESOLUTION
}

\author{
Rahmatullah Khan *
}

\section{INTRODUCTION}

On 7 November 1990, the Supreme Court of India issued a significant Order (Writ Petition No 12819 of 1985 , mimeograph copy) dismissing a petition filed under Article 32 of the Constitution by the Tehri Bandh Virodh Sangarsh Samiti [Tehri Dam Opposition Committee] and others. Petitioners had requested the Court to issue a restraint order to the Government of India preventing it from constructing a huge hydro-power project and a dam on the river Tehri on the ground that the dam posed a serious threat to the life, ecology and environment of the entire northern India as the site of the dam was prone to earthquakes. It was argued that expert testimony indicated that the pattern and consistency of earthquakes in the region were likely to have left a 200 to 300 kilometres length of fracture along the convergence boundary roughly covering the region from Dehradun on the west to the India-Nepal border in the east. Petitioners had good expert testimony on their side.

The project had been considered by the Environmental Appraisal Committee (EAC) of the Ministry of Environment and Forests which unanimously rejected it on the ground that its geological and seismic setting posed grave hazards, and the accompanying ecological and social consequences were unacceptable. Petitioners also highlighted the rather belated note of dissent submitted by Professor V. K. GAUR to the subsequent clearance given to the project by a High Level Committee of

\footnotetext{
* Jawaharlal Nehru Professor of Environmental Law, School of International Studies, Jawaharlal Nehru University, New Delhi; member of the Editorial Board.
}

Ko Swan Sik et al. (eds.), Asian Yearbook of International Law, Volume 2, 11-48 c 1994 Kluwer Academic Publishers. Printed in the Netherlands 
Experts (HLCE) appointed by the Committee of Secretaries. GAUR expressed misgivings about the EAC's competence to judge the safety aspects of the project. The legal contention of the petitioners was that the Government of India had not "applied its mind" to the safety aspect of the project.

The Government of India, on the other hand, maintained that it had considered all aspects of the project, taking the safety aspect into account in the worst case scenario, and that the recommendations of the International Congress of Large Dams on the seismic design of dams had been fully implemented. Reliance was placed, expectedly, on the conclusions of the HLCE which had testified that the seismic potential of the dam-site had been adequately taken into account in the project design. The Government pleadings also noted that it had taken steps to meet Professor GAUR's objections to the proposed dam by soliciting the advice of a renowned expert, Professor JAI KRISHNA, as suggested by Professor GAUR, and that only on the former's recommendation had the Government cleared the project.

The Court confessed that it did "not possess the requisite expertise to render any final opinion on the rival contentions of the experts"; that the design of the dam, the seismic potential and the steps taken to ensure safety were, in the Court's view, "highly intricate questions relating to science and technology": therefore the Court confined itself to an investigation and adjudication of the question "as to whether the Government was conscious of the inherent danger as pointed out by the petitioners and applied its mind to the safety of the dam." The Court was satisfied that the Government had "fully considered every aspect of the project including its safety" which was of "prime importance to the general public" and "did not find any good reason to issue a direction restraining the respondents from proceeding ahead with the implementation of the project." The petition thus failed and was dismissed with no order as to costs.

In addition to the site-specific problem of constructing a large dam in a seismic zone, the Tehri dam attracted a lively discussion on the very desirability of building big dams. An intense agitation against the dam gathered momentum, culminating into the fast-unto-death by a leading environmentalist (SUNDERLAL BAHUGUNA), which was given up at the personal intervention of an equally-committed then Environment Minister (MANEKA GANDHI). The safety factor, despite reassurances of the scientists, continues to haunt the concerned environmentalists, but the main motivation for opposing the Tehri (and other large dams, like the Narmada Valley project, against which a virtual crusade is underway by another environmental activist, BABA AMTE) revolved around the prospect of displacement and consequent destruction of the life-style of huge numbers 
of people, principally tribals, living on lands that will be submerged by the large reservoirs of water. The myriad social and political issues do not figure in the above decision of the Supreme Court of India. The problem was dismissed on a technicality - whether or not the Government had applied its mind to the safety factor. And the agitation is back on the streets or sites of the large dams.

The case presents the dilemmas of the decision-makers, be it an administrator or a judge, around what is popularly captioned as development v. environment. One hesitates to resurrect this debate twenty years after Stockholm and after Founex. The debate is ended; the issue resolved: remove the confrontationist conjunction, i.e. versus; it is environment and development or, better still, sustainable development. The case discussed above, however, exposes the limits of the terminological solutions. It lays bare the ground realities in all their poignancies.

The technological feasibilities and economic advantages of constructing big dams are issues on which there is difference of scientific opinion. Lawyers - and judges - are hardly equipped to resolve the problem. Nevertheless, they help in finding rational solutions, by employing standard techniques of judicial control of administrative discretion. The Tehri Bandh case is a classic example. We have more on this later. This article, however, is not about judicial control of administrative discretion; it is about the role of the judiciary in harmonizing the nation's development goals and its environmental imperatives, as it is played out in India. We will present the constitutional-legislative scenario first for a better perception of the contribution of India's judiciary.

\section{LEGAL FRAMEWORK}

\subsection{Constitutional Provisions}

Although the word "environment" does not figure in the Constitution of India, several provisions in that prolific document deal with almost all the components that constitute environment, i.e., water, air, land, forest, wildlife and so on. The heightened awareness of environment after the Stockholm Conference, in which the then Prime Minister, Mrs. INDIRA GANDHI, participated, led the Government of India to incorporate a direct provision on environment in the Constitution. By the 42nd Amendment, Article 40-A was added, which read: "The State shall endeavour to protect and improve the environment and to safeguard the forests and wildlife of the country." 
The provisions were inserted in Part IV of the Constitution, which part, although non-justiciable, is fundamental to the governance of the country and the State has been enjoined to legislatively implement these directives. Article 37 of the Constitution of India reads:

'The provisions contained in this Part shall not be enforceable by any court, but the principles therein laid down are nevertheless fundamental in the governance of the country and it shall be the duty of the State to apply these principles in making laws.'

It is evident that the provision is jurisprudentially imperfect, as individuals are denied locus standi to protect their right to environment, for the second provision added to the Constitution by the same Amendment spoke of duties of the citizens, rather than rights. Article 51-A states:

It shall be the duty of every citizen of India to protect and to improve the natural environment including forests, lakes, rivers and wildlife, and to have compassion for living creatures.'

The imperfect right embodied in the above provision has been converted into a judicially enforceable right by an imaginative and environmentally attuned higher judiciary of India, which is a different story.

Resuming our constitutional narrative, there are many other provisions in the Constitution which deal with environment, such as Article 47 which provides that the State shall regard the raising of the level of nutrition and the standard of living of its people and the improvement of public health as among its primary duties. Similarly, Article 48 deals with the organization of agriculture and animal husbandry on modern and scientific lines, and Article 49 requires the State to protect every monument or place or object or article of historic interest from spoliation, disfigurement, destruction, removal, disposal or export. An earlier Article (that is 39) containing six clauses obligates the State to secure for its people certain basic social and economic rights, e.g., adequate means of livelihood, safeguarding the health and strength of workers, protection of children and youth against exploitation, equal pay for equal work for both men and women, and so on. The right of the individual to live with "human dignity" and the obligation of the State to ensure "social and economic justice" has posed problems of considerable magnitude to the State, which is discussed under the head "Environment and Development". Continuing our narrative on the constitutional scheme, one more feature that needs to be noted is the Centre-State division of powers.

The legislative and administrative competence of the Union and the States is drawn up in three Lists called the Union List or List I; State List or List II; and the Concurrent list or List III. The Union Parliament is vested with the exclusive power to make laws over matters enumerated 
in the State List. On the other hand, both the Parliament of India and the legislature of any State are competent to make laws with respect to any of the matters enumerated in the Concurrent List. It should be noted that the Indian Parliament has primacy over the State legislature in the field of law-making. By virtue of Article 246, legislation passed by the Indian Parliament concerning matters in the Union and Concurrent Lists are paramount. The Parliament has also been empowered under Article 246 to pass legislation with respect to any matter for any part of the territory of India not included in a State, in spite of the fact that such a matter might have been a part of the State List. Moreover, Article 248, as well as entry 97 of the Union List, vest these residuary powers of legislation in the Union Parliament. The Constitution also provides instances when Parliament can directly legislate in regard to matters falling within the State List. The first instance is found in Article 352 which empowers the Parliament to legislate for two or more States by consent. The Water (Prevention and Control of Pollution) Act, 1974, was passed by the Parliament with the consent of the States.

There is another set of provisions in the Constitution which permits the Union Parliament to make laws even if a matter pertains to the State List. The Union Parliament has been authorized to make any law for the whole or any part of the territory of India for implementing any treaty, agreement or convention with any other country or countries or any decision made at an international conference, association or other body. The supplementary authorization provided in certain entries in the Union List together with Article 253, has the effect of almost shifting legislative competence in regard to matters provided there from the State to the Union List. Many of the important decisions concerning environmental matters are likely to be made at the international level, and will most likely fall within the State Legislature's competence. Hence, the above provision can be invoked by the Centre to give effect to international decisions. In that way, Article 253 and the related entries have great potentiality in terms of future action. The Parliament enacted the Air (Prevention and Control of Pollution) Act, 1981, by virtue of Article 253 (read with entry 13 of List I) of the Constitution. The preamble to the Act states categorically that it was enacted to implement the decisions reached at the 1972 Stockholm Conference insofar as they related to preservation of the quality of air and control of air pollution.

\subsection{Environmental Lex Specialis}

The specific laws adopted in the post-Stockholm period consist of the Water (Prevention and Control of Pollution) Act and Rules, the Air (Pre- 
vention and Control of Pollution) Act and Rules, and the Environment Act and Rules, including their various amendments.'

\subsection{Water Pollution}

The problem of water pollution is sought to be tackled in India by two major Acts: one, the Water (Prevention and Control of Pollution) Act, 1984 (hereafter, the Water Act); and two, the Water Pollution and Prevention Cess Act (the Cess Act). The Water Act seeks to prevent and control water pollution by laying down guidelines and by the establishment of Boards for the purpose. Pollution is defined in sec. 2(E) and, broadly stated, it means such contamination and alteration to the properties of water or such discharge of sewage or trade effluent into water as is likely to create a nuisance, or render such water harmful or injurious to public health.

Chapter 2 of the Water Act provides for the constitution of a Central Board and State Boards for exercising the powers conferred and performing the function assigned to them. Chapter 4 deals with the powers and functions of the Board. Section 17 deals with the functions of a State Board. They include the inspection of the trade effluents and works and plants for the treatment of the trade effluents, and reviewing the plans, specifications and other data relating to treatment plants, and the system for disposal of trade effluent or other works in connection with the grant of consent under the Act, laying down of slandards of trade effluents and the quality for receiving waters resulting from the discharge of such effluents, laying down of treatment of trade effluent to be discharged into a stream, and the making, varying, and revoking of orders for the prevention or abatement of discharges.

Chapter 5 contains the key provisions for preventing and controlling water pollution. Section 20 in this chapter empowers the State Board to

1. The Water (Prevention and Control of Pollution) Act, 1974, as amended by the Amendment Act of 1978,

The Water (Prevention and Control of Pollution) Amendment Act 1988,

The Water (Prevention and Control of Pollution) Rules, 1975,

The Water (Prevention and Control of Pollution) Second Amendment Rules, 1976,

The Water (Prevention and Control of Pollution) Amendment Rules, 1989,

The Water (Prevention and Control of Pollution) Cess Act, 1977,

The Water (Prevention and Control of Pollution) Cess Rules, 1978 Corrigendum,

The Water (Prevention and Control of Pollution) Act, 1987,

The Water (Prevention and Control of Pollution) Amendment Act, 1987,

The Water (Prevention and Control of Pollution) Rules, 1982,

The Water (Prevention and Control of Pollution) (Union Territories) Rules, 1983,

The Water (Prevention and Control of Pollution) (Union Territories) Amendment Rules, 1988

Corrigendum,

The Environment (Protection) Act, 1986,

The Environment (Protection) Act, 1986,

The Environment (Protection) Amendment Rules, 1987 Corrigendum,

The Environment (Protection) Third Amendment Rules, 1987. 
collect information and data about the flow of water in streams by itself; and also gives directions to persons and establishments consuming water to furnish data. Under section 27, the Board can get samples of the effluents and get them analyzed; and under section 22, a copy of the reports of the analysis is to be furnished to the occupier of the factory or premises concerned, and another copy is to be retained for the purpose of use in legal proceedings that may be initiated against him. Section 23 empowers any person authorized by the Board to entur any place for performing the functions entrusted to him; he can inspect the place and meet non-compliance with notices, orders or directions of the Board. Plans, records, documents and material objects can be examined if the commission of an offence is suspected.

Section 24 states that no person shall knowingly cause or permit any poisonous emission or polluting matter (determined in accordance with the standards laid down by the Board) to enter any stream or well; or discharge into the stream any other matter likely to impede the flow of water. Section 25 (1) provides that no person shall, without the previous consent of the Board, bring into use any new or altered outlet for discharge of trade effluent, or begin to make any new discharge. The consent can be obtained by making an application to the Board under sub-section 2. After making an inquiry under sub-section 4 , the Board can give its consent, subject to conditions as to the point of its discharge, construction and use of the outlet, and the nature, composition and rate of discharge of the trade effluent. Even when an outlet is brought into use, if the new discharge is made without obtaining consent, the Board can by notice impose such conditions under sub-section 5 . Section 26 extends the provisions of section 25 to "existing discharges".

Under section 27 the Board can review the position from time to time. Section 28 and 29 deal with appeals and revisions. Section 30 empowers the Board to carry out the works in regard 10 conditions imposed by it, where the occupier commits default. When the Board apprehends that the water in a stream is likely to get polluted by reason of any matter therein it can apply to a Magistrate, under section 33, to restrain the person responsible from doing what is apprehended; and the court can pass appropriate orders, including an order to the person concerned to desist from making such discharge. Sections 41 to 46 deal with offences and penalties. Violations of a Magistrate's order issued under section 33 can be punished with imprisonment up to three months and with a fine. Contraventions of sections 24,25 and 26 will lead to imprisonment for not less than six months and provision is also made for enhanced penalty for continuing offences. In case of a second conviction, the offender's name can 
also be published in newspapers. Section 58 bars the jurisdiction of civil courts and section 60 gives overriding effect to the provisions of the Act.

The Cess Act is designed to give financial muscle to the Central and State Boards in order for them to carry out their functions properly. Section 3 provides a levy and collection of a cess for the purpose of preventing pollution. The levy is to be calculated on the basis of water consumed and at rates not exceeding those specified in schedule 2. Section 4 provides for installing meters for measuring consumption of water. Section 5 requires every person liable for payment of cess to furnish returns to the prescribed authority. The authority is to made assessments under section 6 on the basis of particulars furnished in the returns. Section 7 provides for grant of rebate to those consumers who install plants for treatment of trade effluents. Section 10 provides for collection of interest in cases of delayed payment of the cess, and section 11 for imposition of penalty. Section 12 authorizes the recovery of dues by resort to revenue recovery proceedings. Section 17(1) confers power on the Central Government to make rules for carrying out the purposes of the Act, and subsection (2) enumerates matters on which provision would be made in the rules. In pursuance to section 17 , rules have been framed by the Government which are designated as the Water (Prevention and Control of Pollution) Cess Rules, 1978. Rule 2(B), for instance, prescribes that in relation to the State, the assessing authority shall be the member-secretary of the State Board. Rule 4 provides for submission of returns of consumers every month in form 1. Rule 6 deals with the grant of rebate; Rule 7 with the expiry dates; Rule with the composition of the valid authority; and under Rule 15 industries are specified in schedule 1 of the Act falling within the ambit of the Act.

\subsection{Air Pollution}

At the United Nations Conference on the Human Environment held in Stockholm in June 1972, in which India participated, decisions were taken to take appropriate steps for the preservation of the natural resources of the earth which, among other things, included the preservation of the quality of air and control of air pollution. The Government of India decided to implement those decisions in so far as they related to the preservation of the quality of air and control of air pollution in the Air (Prevention and Control of Pollution) Act, 1981. The Act was enacted under Article 253 of the Constitution to implement the decisions taken at the Stockholm Conference. 
Under the Act, the Central Pollution Control Board and State Pollution Control Boards, set up under Articles 3 and 4 respectively, have the following powers:

Under Article 16(2), the Central Board may

(a) advise the Central Government on any matter concerning the improvement of the quality of air and the prevention, control or abatement of air pollution;

(b) plan and cause to be executed a nation-wide programme for the prevention, control or abatement of air pollution;

(c) coordinate the activities of the State Boards and resolve disputes among them;

(d) provide technical assistance and guidance to the State Boards, carry out and sponsor investigations and research relating to problems of air pollution and prevention, control or abatement of air pollution;

(e) plan and organize the training of persons engaged or to be engaged in programmes for the prevention, control or abatement of air pollution in such terms and conditions as the Central Board may specify;

(f) organize through mass media a comprehensive programme regarding the prevention, control or abat cment of air pollution;

(g) collect, compile and publish techuicial and statistical data relating to air pollution and the measures devised for its effective prevention, control or abatement and prepare manuals, codes or guides relating to prevention, control or abatement of air pollution;

(h) lay down standards for the quality of the air;

(i) collect and disseminate information in respect of matters relating to air pollution.

Similarly, under Article 17, the State Board shall have the power to:

(a) plan a comprehensive programme for the prevention, control or abatement of air pollution and to secure the execution thereof;

(b) advise the State Government on any matter concerning the prevention, control or abatement of air pollution;

(c) inspect, at all reasonable times, any control equipment, industrial plant or manufacturing process and to give, by order, such directions to such persons as it may consider necessary to take steps for the prevention, control or abatement of air pollution;

(d) inspect air pollution control areas at such intervals as it may think necessary, assess the quality of air therein and take steps for the prevention, control or abatement of air pollution in such areas;

(e) lay down, in consultation with the Central Board and having regard to the standards for the quality of air laid down by the Cen- 
tral Board, standards for emission of air pollutants into the atmosphere from industrial plants and automobiles or for the discharge of any air pollutant into the atmosphere from any other source whatsoever not being a ship or an aircraft.

Under Article 19(3), "[i]f the State Government, after consultation with the State Board, is of opinion that the use of any fuel, other than an approved fuel, in any air pollution control arra or part thereof, may cause or is likely to cause air pollution, it may, hy notification in the official Gazette, prohibit the use of such fuel in such area or part thereof with effect from such date as may be specified in the notification" (emphasis added). Article 19(4) states that the State Government may, after consultation with the State Board, by notification in the Official Gazette, direct that with effect from such date, as may be specified therein, no appliance, other than an approved appliance, shall be used in the premised situation in an air pollution control area. Under Article 19(5), if the State Government, after consultation with the State Board, is of opinion that the burning of any material, in any air pollution control area or part thereof, may cause or is likely to cause air pollution, it may, by notification in the official Gazette, prohibit the burning of such material in such area or part thereof.

Article 21 stipulates that no person shall, without the previous consent of the State Board, establish or operate any industrial plant in an air pollution control area. Also, under Article 22, no person operating any industrial plant in any air pollution control area shall discharge or cause or permit to be discharged the emission of any air pollutant in excess of the standards laid down by the State Board. By virtue of Article 37, whoever fails to comply with the provisions of section 21 or section 22 or directions issued under section $31 \mathrm{~A}$ shall, in respect of each failure, be punishable with imprisonment for a lerm whic/l shall not be less that one year and six months but which may extend 10 six years and with fine, and in case the failure continues, with additional tine which may extend to five thousand rupees for every day during which such failure continues after the conviction for the first such failure. If the failure referred to in sub-section (1) continues beyond a period of one year after the date of conviction, the offender shall be punishable with imprisonment for a term which shall not be less than two years, but which may extend to seven years and with fine (Article 37(2)).

Where an offence under this Act has been committed by any Department of Government, the Head of the Department shall be deemed to be guilty of the offence and shall be liable to be proceeded against and punished accordingly (Article 41). Provided that nothing contained in this section shall render such Head of the Department liable to any punish- 
ment if he proves that the offence was committed without his knowledge or that he exercised all due diligence to prevent the commission of such offence.

\subsection{The Environment (Protection) Act, 1986}

Perhaps realizing the deficiencies of adopting legislation in sectors, and obviously to fill the gaps left out in the aforesaid legislations, the Government of India passed the Environment (Protection) Act on 23 May 1986. The preamble to this Environment Act (as it will be referred to hereafter) identifies the decisions taken at Stockholm as the inspiration and source of authority. As such, it applies to the whole of India.

By virtue of the Environment Act, Iho ('ntrial Government assumes the power to take all such measures as it decms necessary or expedient for the purpose of protecting and improvin!s ller quality of the environment and preventing, controlling and abating environmental pollution. In particular, the powers claimed include coordinating the actions of State Governments, planning and executing nation-wide programmes, laying down emission and effluent standards, restricting operation of industries in some areas, ensuring safety procedures, and so on. The Central Government can constitute an authority or appoint officers to carry out the purposes of this Act. It can give directions, make rules, and establish procedures in furtherance of the objectives of this Act.

The Environment Act authorizes the Central Government to regulate handling of hazardous substances. The Act empowers the designated officers to inspect factories, take samples of emissions and effluents, have an analysis made in established or designated laboratories, and punish offenders. The punishment under this Act is quite severe: a prison term up to five years and fine of about a hundred thousand rupees; continuous violations attracting additional five thousand rupees a day and the prison term extendable to seven years in case of persistent contraventions beyond one year. The Environment Act contains a curious provision [section 24(2)] under which if an offence is punishable under this Act as well as any other Act (the Water Act, for instance) the offender "shall be liable to be punished under the other Act and nol under this Act". This provision enables the offender to choose a lesser pumishment, as the penalty provisions of the other Acts (e.g., the Watcr $\Lambda \cdot 1)$ are, as seen above, not as stiff as those of the Environment Act. 


\subsection{The Wild Life (Protection) Act, 1972}

The rapid decline of India's wild animals and birds, one of the richest and most varied in the world, has been a cause of grave concern. Hence the legislation seeks to:

(a) constitute a Wild Life Advisory Board for each State;

(b) regulate hunting of wild animals and birds;

(c) lay down procedures for declaring areas as sanctuaries, national parks, etc.;

(d) regulate possession, acquisition or transfer of, or trade in, wild animals, animal articles and trophies and taxidermy thereof;

(e) provide penalties for the contravention of the Act.

Under Article 18 of the Act (chapter IV), the State Government may, by notification, declare any area to be a sanctuary if it considers that such area is of adequate ecological, faunal, floral, geomorphological, natural or zoological significance, for the purpose of protecting, propagating or developing wild life or its environment. Under Article 35, whenever it appears to the State Government that an area, whether within a sanctuary or not, is, by reason of its ecological, faunal, floral, geomorphological or zoological association or importance, mercled to be constituted as a national park for the purpose of prolectiny, propragating or developing wild life therein or its environment, it mily by notification declare its intention to constitute such area as a national park. Under Article 51, any person who contravenes any of the provisions of this Act shall, on conviction, be punishable with imprisonment for a term which may extend to two years, or with fine which may extend to two thousand rupees, or with both.

\subsection{The Indian Forest Conservation Act, 1980}

With a view to checking further deforestation, an Ordinance was promulgated, but in 1980 a regular Act replaced the Ordinance. The Forest Conservation Act, 1980, was passed by the Parliament to provide for conservation of forests and for matters connected therewith or ancillary thereto. According to the statement of objects of the said Act deforestation caused ecological imbalances and led to environmental deterioration. It recognized that deforestation had been taking place on a large scale in the country, which had caused widespread concern.

This Act deals with reserved, protected, and village forests in pursuance to the national Forest Policy of 1952. The 1980 Act was formulated on six paramount needs of the country, inter alia, the need for checking: 
(a) the denudation in mountainous regions, on which depends the perennial water supply of the river system whose basins constitute the fertile core of the country;

(b) the erosion causing havoc to the space along the treeless banks of the great rivers leading to ravine formation and on vast stretches of undulating waste-lands deprivin!s the adjoining fields of their fertility;

(c) the need for establishing tree-cover, whenever possible, for the amelioration of physical and climatic conditions, promoting the general well-being of the people.

In the case of all forests, the forest officer has very wide-ranging powers to stop paths and water courses, to prevent/restrict entry, etc. He can prohibit (section 26) clearing of forests, setting fire to a forest or kindling of any fire which endangers a forest, removing any forest produce. This provision is especially detrimental to the tribals who live on forest produce.

However, under section 27, the State Government can declare an area a reserved forest or dereserve the same. This has been a subject of debate, which will be discussed later (3.3).

\subsection{The Motor Vehicles Act, 1988}

The statement of objects and reasons of the 1988 Act notes that various committees, like the National Transport Policy Committee, the National Police Commissioner, the Road Safety Committee, the Low-Powered Two Wheelers Committee, and the Jaw Commission have recommended the updating, simplification and ralionalisation of the earlier 1939 Law. Some of the more important modificalions of the 1988 law take care, inter alia, of

- the need for encouraging and the acloption of higher technology in the automotive sector, and

- demonstrating concern for road safety standards, pollution-control measures, standards for transportation of hazardous and explosive materials.

Section 109 requires every motor vehicle to be so constructed and maintained as to be at all times under the effective control of the person driving the vehicle. Section 110 authorizes the Central Government to make rules relating to construction and maintenance of vehicles in the matters of:

(g) the emission of smoke, visible vapours, sparks, ashes, grit or oil;

(h) the reduction of noise emitted by or caused by vehicles; 
(i) provision for transportation of goods of dangerous or hazardous nature to human life;

(j) standards for emission of air pollutants.

The Central Motor Vehicle Rules, 1988, have been formulated to lay down detailed provisions in this regard. Rules 112, 113, 114 deal with smoke, vapour, ashes, grit and oil. Rule 112 stipulates that exhaust gases should escape only on the right rear of the vehicles. The exhaust pipe should be at least $35 \mathrm{~mm}$ from the fuel line connecting the fuel tank and engine. Rule 115 provides for the level of carbon monoxide and smoke emission by vehicles. Rule 119 provides for the type of horns to be used in vehicles and kind/level of noise that can be produced. Under Rule 120 , every vehicle should be fitted with silencers to reduce noise. Rule 129 specifies that every owner of vehicle transporting any dangerous or hazardous goods shall display the appropriate label of the class of goods he is transporting. The size and positioning of the label is specified in Rule 130. Under Rule 133, the driver of a vehicle transporting dangerous or hazardous goods is required to take all due precautions. Table III of the Rules lists the hazardous and toxic substances.

The above Indian lex specialis on environment has generated quite a bit of debate and has led to a good deal of litigation. In the process India's judiciary has had to deal with a new branch of law on the basis of an often deficient legislation. It overcame the problem by resurrecting old Common Law concepts, like nuisance, and by applying the Tort law rules on liability, etc.. More problematic were some substantive and processual issues, such as (i) "judicial control of administrative action", (ii) "standing" and (iii) evaluation of "expert testimony". The toughest task that India's judiciary was called upon to perform related to (iv) the resolution of claims to development posited as conflicting with a healthful environment. The next part discusses the first and fourth substantive issues at length.

\section{JUDICIAL CONTROL OF ADMINISTRATIVE DISCRETION}

Courts of India have demonstrated considerable courage in grappling complex environmental issues brought to their attention. In more than one case, courts were confronted with the problem of judging the legal propriety of administrative action. The standard argument was that the impugned administrative decision did not take into consideration the ecological imperative. The court in such cases employed the time-tested instrumentality of judicial control of administrative action, that is, that the administrative action should be fair, just and proper, and that the 
authority concerned should apply its mind to all the aspects of the problem including the environmental aspect, and that the decision should not be arbitrary. In Sachidanand Panday v. State of West Bengal, ${ }^{2}$ the Government of West Bengal was accused of showing lack of awareness of the problem of environment in making an allotment of land for the construction of a five-star hotel at the expense of the zoological garden.

The said zoo was situated in about 40 acres. The area proposed to be given for hotel construction was already in use by the zoo for fodder cultivation, burial ground for dead animals, an animal hospital, operation theatre, quarantine area, segregation wards, post-mortem room, a nursery for zoo animals and a horticulture section. Petitioners contended that the construction of a multi-storied building in the near vicinity of the zoo would be highly detrimental to the animals of the zoo, its ecological balance, and would adversely affect the bird migration which was one of the greatest attractions of the zoo.

The Court posited the ecological challenge in terms of administrative action as follows:

"If the Government is alive to the various considerations requiring thought and deliberation and has arrived at a conscious decision after taking them into account, it may not be for this Court to interfere in the absence of mala fides. On the other hand, if relevant considerations are not borne in mind and irrelevant considerations influenced the decision, the Court may interfere in order to prevent a likelihood of prejudice to the public" (p. 305).

Noting the law laid down in Articles 84-A and 51-A(g) of the Constitution, the Court stated that although it was the responsibility of the policymaking authority to devise the ways and means of implementing these Directive Principles, the Court had a duty to ensure that appropriate considerations were borne in mind and irrelevancies excluded. In appropriate cases, the Court stated, it could issue necessary directions. The Court added a very important caveat:

"However the Court will not attempt to nicely balance relevant considerations. When the question involves the nice balancing of relevant considerations, the Court may feel justified in resigning itself to acceptance of the decision of concerned authority" (p. 305).

In the present case, the Court did not have to weigh the environmental variable as against other variables. For one thing, there was no destruction of ecology, but only a replacement of the facilities (animal hospital, burial ground, fodder cultivation, and so on). The beneficiary of the landallotment, the Taj Group of Hotels, had assured the West Bengal Govern-

2. (1987) 2 Supreme Court Cases 295. 
ment that the services and facilities would be reconstructed on the premises of the Zoological Garden, which assurance was incorporated in the deed of lease. In order for the Court to make a determination that the impugned decision was not arbitrary, all that the Court had to do was to ensure that the inconveniences involved in the execution of the decision were taken cognizance of and that alternative arrangements had been made, which was abundantly made clear in this case.

The Court noted that the decision of the Government was taken openly, that it had ensured the improvement of the existing facilities which were "in shockingly unkept conditions" and that the old hospital "housed in a semi-dilapidated building" was replaced with a "modern zoo hospital". The Court also noted with satisfaction that the Taj Group of Hotels had waived their right to claim reimbursement of the money spent towards the cost of new constructions, which was Rs. 30 lakhs. The administrative decision was thus unimpeachable.

The question as to whether the Government was alive to the ecological considerations also posed no particular problem for the Court. The Court took note of the fact that the decision preceded two years of deliberation, that the Chief Minister had some correspondence with the Prime Minister, who had expressed fears that the construction of a high-rise building would hamper the trajectory of the migrating birds, and so on. The assurance on this score given by the West Bengal Chief Minister to the Prime Minister of India, together with the one given by J.R.D. TATA of the Taj Group of Hotels, convinced the Court that the ecological aspect was adequately gone into. The Court noted that there were taller buildings in the vicinity which had not hampered the flight of the birds, that the proposed facility was a garden hotel which would improve the ecology and environment of the land concerned. It also felt reassured by the expert opinion endorsing the hotel management's reassurance.

SACHIDANAND PANDEY thus did not pose to the Court any unenviable or insuperable problem of balancing the ecological element against any other element or elements. The cost to ecology was non-existent; in fact, the environment stood to gain in terms of improvement of the facilities. In other cases, the cost could be high, as the Court soon found out.

Not every conflict between environment and development is susceptible to an easy solution. In the SACHIDANAND PANDEY case animals in captivity could easily be moved from one site to another without great damage. The builder of the five-star hotel - if that activity could be subsumed under development - as well as the Government were all too willing to provide for the animals an alternative site with improved facilities. Here was a case where environment and development could be easily harmo- 
nized. But things could get tough; as is the case with the Konarak sanctuary.

The Oberoi Group of Hotels wanted to construct a five-star hotel by the side of this mecca of tourists in search of oriental erotica. Wanting to provide sylvan surroundings for the proposed facility, the Oberoi Group applied for a large chunk of the nearby sanctuary populated by the buck, deer and other animals. The 70-acre sanctuary with rich casuarina, touching the beach with a unique ecosystem was declared as a protected forest in 1978 under the Orissa Forest Act. In 1984, the same stretch of forest was included in the notification declaring the much larger BalakhundaKonarak wildlife sanctuary.

In 1987, the Orissa Government issued an order withdrawing the 1978 notification. The Konarak area was dereserved and the Oberoi Group application was approved. The requirement under the Forest Conservation Act of 1980 of obtaining the Ministry of Environment and Forest's permission for dereservation of reserved forests and the necessity of a recommendation of the chief wildlife warden and the principal conservator of forests was given the go-by. In fact, the then Minister of Environment and Forest, Z.R. ANSARI, and the chief wildlife warden and the principal conservator of forests, according to a leading commentator on environment, ClAUDE ALVARES, ${ }^{3}$ strongly protested against the Orissa Government's move, but in vain. The case, ignoring innuendos about financial improprieties and kick-backs, presents a classic case of environment and development in which development receives an undue priority.

In M.C. Mehta v. Union of India ${ }^{4}$, the petitioner requested appropriate action against some 75 tanneries located on the banks of the river Ganga at Jajmau near Kanpur. The tanneries discharged trade effluents causing damage to the life of the people who used the water of the river Ganga and also to the aquatic life in the river. The effluents in question were ten times as strong as domestic sewage. As the committee constituted by the Directorate General of Technical Development (Government of India) testified, the waste water discharge by the tanneries "contains putrescible organic and toxic inorganic materials which, when discharged as such, would deplete the dissolved oxygen content of the receiving water courses resulting in the death of all aquatic life and emanating foul odour". The committee also stated that the untreated effluents polluted ground water resources and their discharge into public sewers resulted in the choking of the sewers.

3. See, "Sanctuary in Peril", The Illustrated Weekly of India, 16 September 1990, pp. 46-47.

4. AIR 1988 SC 1037.

5. Ibid, p. 1042. 
The Court noted expert testimony to the effect that 60 tanneries in Jajmau produced 12,000 hides and discharged five million litres of waste water per day. It also recorded another expert opinion commissioned by the Department of Environment more or less endorsing the said data. On the basis of such expert opinion, the Court came to the conclusion that the Ganga was grossly polluted, specially near the towns situated on its banks.

Interestingly, there was no dispute about either the volume or deleterious quality of the effluents of the tanneries. The only defence put up by 47 industries, out of the 75 impugned, was couched in the classical environment $\mathrm{v}$. development terminology. Counsel for the tanneries argued that the tanneries generated employment and that the enormous cost of the treatment of installing treatment plants would inhibit their normal functioning and growth. The Hindustan Chamber of Commerce, of which 43 respondents were members, brought to the notice of the Court that 6 of the tanneries had already set up primary treatment plants, that 14 of them were about to construct such plants. The organization pointed out that an enormous expenditure would be incurred if all tanneries were to install the said treatment plants: the cost of a pre-treatment plant for ' $\mathrm{A}$ ' class tannery was Rs. 368,000 ; the cost of the plant for a ' $\mathrm{B}$ ' class tannery was Rs. 50,000 . The Court was not persuaded by the above argument. It said:

'This cost does not appear to be excessive. The financial capacity of the
tanneries should be considered as irrelevant while requiring them to estab-
lish primary treatment plants. Just like an industry which cannot pay mini-
mum wages to its workers cannot be allowed to exist, a tannery which
cannot set up a primary treatment plant cannot be permitted to continue
to be in existence for the adverse effect on the public at large which is
likely to ensue by the discharging of the trade effluents from the tannery to
the river Ganga would be immense and it will outweigh any inconvenience
that may be caused to the management and the labour employed by it on
account of its closure.

The Court issued an order directing all the tanneries that did not have primary treatment plants to stop working. As for those that had already put up such plants the direction was that they should keep their primary treatment in working order. Those that had promised to establish primary treatment plants were ordered to do so within six months.

The judgement is noteworthy for the source of authority invoked for the issue of orders and directions noted above. "Under the laws of the land the responsibility for treatment of the industrial effluents is that of

6. Ibid, p. 1045. 
the industry", stated the Court, and added: "While the concept of "strict liability' should be adhered to in some cases, circumstances may require that plans for sewerage and treatment systems should consider industrial effluents as well." ${ }^{77}$ The Court did not find any circumstances to exonerate the industry from strict liability. As noted, it dismissed the argument based on costs. "For every breach of a right", the Court ruled, "there should be a remedy. ${ }^{n 8}$ Justice K.N. SiNGH, in a separate opinion, dismissed the supposed dichotomy between environment and development with the crisp, but effective, conclusion: "We are conscious that closure of tanneries may bring unemployment, loss of revenue, but life, health and ecology have greater importance to the people. ${ }^{n 9}$

\section{DEVELOPMENT V. ENVIRONMENT}

Courts in India have grappled with the problem of balancing the ecological imperatives with the developmental needs of the country in a large number of cases that came up before them. One such set of cases related to the mining operations in Doon Valley. The Rural Litigation and Entitlement Kendra, Dehradun v. The State of Uttar Pradesh ${ }^{10}$ was the first case that came up before the Supreme Court in which this conflict was sought to be resolved. The Supreme Court noted the havoc caused to the environment of the region by mining operations which had been a matter of concern of a number of committees, one of which was appointed by the Government itself. Of the three categories of limestone quarries, one was found by that committee to have done considerable harm to the ecology of the region. The Court therefore ordered their closure forthwith. There were two other categories of limestone quarries that were classified by one committee and lumped together by another. The Court ordered the closure of those of the quarries which were within the municipal limits of Dehradun, but allowed a few to continue with a clear directive that they should take into consideration the ecological needs of the region and that they should take precautionary measures so that the environment was not further damaged. The Court also ordered the quarries to conform to the safety regulations of the Mines Act, which was to be supervised by a committee appointed by the Court.

\footnotetext{
7. Ibid, p. 1044.

8. lbid, p. 1046.

9. lbid, p. 1048.

10. AIR 1985 SC 652.
} 
The Court was confronted with the problem of the developmental needs of the region and was particularly informed that the closure of the mining operations would result in the laying off of a number of workers which would result in acute unemployment in the region. The Court took the position that its action would undoubtedly cause hardship to them, but argued that it was a price that had to be paid for protecting and safeguarding the rights of the people to live in a healthy environment with minimal disturbance of the ecological balance and with avoidable hazard to them and to their cattle, homes and agricultural land. It nevertheless saw the need to mitigate the hardship caused by the closure of the quarries by directing the Government of India and the State of Uttar Pradesh to give preference to the owners of the quarries whenever new licenses for quarrying were given by the respective governments. The Court also ordered immediate steps to be taken for reclamation of the areas forming part of such limestone quarries with the help of the already available EcoTask-Force of the Department of Environment, Government of India, and the workmen who were thrown out of employment in consequence of that order were, "as far as practicable and in the shortest possible time" were to be provided employment in the afforestation work and soil conservation programmes to be taken up in the area.

Allegations were made of unauthorized and illegal mining operations in the Mussouri Hills and the area around. The Court considered the letter received from the Rural Litigation Kendra, along with the accompanying affidavits, and treated it as a writ petition. The Court decided on 11 August 1982, after hearing the counsel of parties, to appoint a committee for inspecting all the mines other than those belonging to the State of U.P. and the Union of India, with a view to determining whether or not the safety standards laid down in the Mines Act, 1952, and the Mines Rules made thereunder were being observed and whether there was any danger of landslides on account of the quarrying operations, particularly during the monsoons, in any of the mines and if there was any hazard to the individuals, cattle or agricultural lands by reason of the mining operations. The Court-appointed committee came to be known as the Bhargawa Committee and its members were authorized to inspect the mines and give suitable directions. As stated, the Bhargawa Committee classified the mines in the area into three groups, " $\mathrm{A}$ ", " $\mathrm{B}$ " and " $\mathrm{C}$ ". As far as the mines in group " $\mathrm{C}$ " were concerned, the Committee was of the view that they were not suitable for continuance and should therefore be closed down, and as the group " $\mathrm{A}$ " mines were concerned, the Committee was of the opinion that the quarrying could be carried on without environmental or ecological hazards. 
The judgement was delivered by RANGANATH MisRA, J. and P.N BHAGAWATI J. The judgement contains an erudite discussion of the problems of the Himalayan Range. It noted that this range of mountains had constituted the northern boundary of the country and until recent times had provided an impregnable protection to the Indian sub-continent from the northern direction. The Court also pointed out that the mountain range was responsible for regulating the monsoon and consequently the rainfall in the Indo-Gangetic belt. The Himalayas, the Court stated, were the source of perennial rivers - the Ganga, Yamuna and Brahamaputra and several other tributaries which joined those main rivers. For thousands of years, declared the Court, nature had displayed its splendour through the lush green trees, innumerable springs and beautiful flowers. The Himalayas had been a storehouse, the Court added, of herbs, shrubs and plants. The perennial water streams and the fertile soil had contributed, not only to the growth of dense, lush green forests, but had helped the yield of Basmati rice and leeches. The Court added that Mussouri, known as the queen of hill stations, situated at a height of 5,000 feet above sea-level, and Dehradun located below, were important places of tourist attraction, centres of education and research and a defence complex.

The Court stated that the valley was in danger because of erratic, irrational and uncontrolled quarrying of limestone. The landscape, the Court found, had been stripped of its verdant cover. The green cover today was only about 10 percent of the area, while some years ago it was almost 70 percent. Tracing the history of mining operations, the Court stated that there were 105 mining leases and that the limestone dug out from these quarries was useful for the manufacture of a special kind of steel. The U.P. Government had pleaded that the quarrying was in the national interest and that without this special kind of steel, which was used primarily in the manufacturing of defence equipment, the security of the nation would be jeopardized. The Court, however rejected this argument.

The Court paid obeisance to the prerogative of the Executive to decide the national priorities and whether the deposits should be exploited at the cost of the ecology and environmental considerations or whether the industrial requirement should be satisfied. It stated that it was perhaps possible to exercise greater control and vigil over the operation and strike a balance between the preservation and utilization that would indeed be a matter for an expert body to examine. On the basis of appropriate advice, the Government should take a policy decision and firmly implement the same. However, the Court ruled that the Governments both at the Centre and the State must realize and remain cognizant of the fact that the stake involved in the matter was large and far-reaching. The evil consequences of such mining could last long. Once that unwanted sit- 
uation set in, the Court pointed out, amends or repairs would not be possible and it declared that the greenery of India might perish and the Thar desert may expand its limits. By specific reference to the Stockholm Declaration of June 1972, the Court stated that it was necessary that the Himalayas and the forest growth in the mountain range should be left uninterfered with so that there might be sufficient quantity of rain. The Court also stated that the top-soil might be preserved without being eroded and the natural setting of the area may remain intact. It urged the State Government to undertake a massive afforestation programme to remedy the harm already done to the region and to tap, for purposes of social development, the natural resources of the region with the requisite attention and care to the ecology and environment. The Court stated that it had always to be remembered that those were permanent assets of mankind and not intended to be exhausted in one generation. "Significantly", the Court noted, "preservation of the environment and keeping the ecological balance unaffected is a task which not only governments but also every citizen must undertake. It is a social obligation and let us remind every Indian citizen that it is a fundamental duty as enshrined in Article $51(\mathrm{~g})$ of the Constitution."

It is not difficult to see in this judgement that the Court had only paid lip service to the authority or power of the Executive to decide or make policy decisions concerning the exploitation of natural resources and to take care of the developmental needs of the society. But then it had gone on to make that decision itself by ordering the closure of mines in the Doon Valley on the justifiable ground of preserving the environment. This judgement led to further litigation and, in 1988, the Court was confronted with the problem once again. In the Rural Litigation and Entitlement Kendra v. State of Uttar Pradesh ${ }^{11}$ the Court explained its own jurisdiction to entertain a writ petition of the kind before it. The Court was faced with the argument that under the Environment (Protection) Act, 1986, the power was vested in the Central Government to take measures to protect and improve the environment. It was argued that the vesting of such power with the Central Government left no room for the Court to intervene in such matters. The Court stated that the Act did not purport to, and perhaps could not, take away the jurisdiction of the court to deal with a case of this type.

RANGANATH MISRA J. in this particular decision was even more picturesque in his description of the ecology of the region. The learned judge cited Kalidasa's Meghadoot to sing the glories of the Himalayas and repeated his earlier description of the cultural importance of the Ganga

11. AIR 1988 SC 2187. 
and the Yamuna which provided the backdrop to Krishna Lila. He noted the contribution made by the Himalayas to the culture of the country and cited Athurvaveda to the effect that man's paradise was on earth and that the living world was the most beloved place of all. There were a number of passages in the judgement of RANAGATH MISRA J. dealing with the scientific significance of the Himalayan Range. The learned judge quoted reports of scientific institutions like the Birla Institute of Scientific Research to the effect that nearly 6,000 million tonnes of soil was washed away in floods every year, which was because of the deforestation of the Himalayas.

Addressing the problem of balancing the national security interests and development, on the one hand, and the ecological imperatives, on the other, the Supreme Court did the balancing itself by taking into consideration the statistics advanced by the Government of the Union of India in an affidavit on the requirement of the special steel which was manufactured by the lime extracted from the Doon Valley. It noted that the data furnished by the mine owners of the quarries in question showed that a total of 173,768 tonnes had been supplied to the steel plants from the Dehradun-Mussouri area during 1986 which was approximately 25 percent of the limestone production. Taking further into consideration the requirements of the sugar industry and the manufacture of chemicals and paper, which were also projected as the demands of development as against the environmental imperative, the Court noted the said requirements of the industries and dismissed the argument that the national interest or the foreign exchange requirements of the country or even the fact that the industries would be hard hit if mining activities in the Dehradun-Mussouri area were stopped. It stated that once the importance of forests was realized and the preservation of the same was accepted as a goal, nothing which would detract from that end should be permitted. The Court stated that trade would adjust itself to new circumstances. It reaffirmed its earlier decision to order closure of some of the mines which had clearly created hazard to the environment.

\section{CASES UNDER THE FOREST (CONSERVATION) ACT, 1980}

The Act extends to the whole of India, except the State of Jamu and Kashmir. Section 2 of the Act provides as follows: "Restriction on the dereservation of forests or use of forest land for non-forest purpose: Notwithstanding anything contained in any law for the time being in force in a State, no State Government or any other authority shall make, except with the prior approval of the Central Government, any order directing: 
(1) that any reserved forest land or any portion thereof may be used for any non-forest purpose..." Explanation for the purposes of this section: "non-forest" purpose means breaking up or clearing of any forest land or any portion thereof for any purpose other than reforestation). It will be seen that the section makes it obligatory for the State Government to obtain permission from the Central Government for dereservation of the reserved forest and for the use of forest land for non-forest purposes. It is apparent that two situations were intended to be prevented by the legislation in question, namely, dereservation of reserved forest and use of forest land for non-forest purposes.

A number of cases came up for consideration of the various High Courts or even the Supreme Court arising out of an interpretation of this particular section of the 1980 Act. One such case was the Ambica Quarries Works v. The State of Gujarat. ${ }^{12}$ The Supreme Court was confronted in this case with the difficult, but persistent problem of striking a balance between the need for exploitation of the mineral resources lying hidden in the forests and the need to arrest the environmental deterioration of forests. The appellant had been granted a quarry lease for a minor mineral at site no. 73 of village Morai of Taluka Pardi in the district of Valsad in the State of Gujarat. The lease was granted on or about 29 November 1971 for a period of 10 years. The area comprised 13 acres of land for quarrying purpose. Three persons were granted two and half acres of land each and the remaining five and half acres land were placed at the disposal of the Industries, Mines and Power Department for the purpose of granting quarrying lease for the same. The case of the appellant was that the said lands were dereserved from the forest area of land since 1971. On or about 3 August 1981, when the lease was about to expire, the appellant applied for renewal of lease as per rule 18 of the Gujarat Minor Mineral Rules, 1966. The application was rejected by the Assistant Collector, Valsad on the ground that the land fell under the reserved forest area and hence the Forest Department of the State of Gujarat refused to give a "no objection" certificate. The contention of the appellant was that by the order dated 29 November 1971, the Forest Department had dereserved the said area and had allotted the land for quarrying by the appellant. It was further contended that the land was under the control of the Industries, Mines and Power Department, hence the 1980 Act did not apply to the same. The High Court of Gujarat dismissed the petition and the appellant went to the Supreme Court.

Counsel for the appellant argued before the Supreme Court that there was no question of extending the land in question to non-forest purposes,

12. AIR 1087 SC 1973. 
and that at the relevant time when the request for renewal was made, the site of mining was already a dereserved forest. Therefore it was argued that the two conditions of section 2 of the 1980 Act were not applicable to the situation. Counsel also relied heavily on a case decided by the Supreme Court itself in which the Court had permitted the respondent to continue the mining operations even after the coming into force of the 1980 Act. The case under reference was State of Bihar v. Banshi Ram $M o d i^{13}$ where a mining lease for extracting mica was granted by the State Government in respect of an area of 80 acres of land which formed part of the reserved forest before the coming into force of the 1980 Act. However, the forest land had been dug up and mining operations were being carried on only in an area of five acres out of the 80 acres allotted. During the mining operations, the respondent came across two associate minerals, namely feldspar and quartz, in the area. He therefore made an application to the State Government for the execution of a deed of incorporation to include the said minerals also in the lease. Though the 1980 Act had come into force, the State Government executed the deed incorporating these items without obtaining prior sanction of the Central Government under section 2 of the 1980 Act. Since the respondent in that case made a statement to the Court that he would carry on the mining operations only on five acres of land which had already been utilized for non-forest purposes even before the Act came into force, the question for determination was whether prior approval of the Central Government under section 2 of the 1980 Act was necessary for the State Government for granting permission to include the associate minerals also within the same area of five acres of land.

The Supreme Court answered the question in the negative and upheld the judgement of the High Court. The Court stated in Banshi Ram Modi that the result of taking the contrary view would be that while the digging for purposes of winning of mica could go on, the lessee would be deprived of collecting feldspar or quartz which he might come across while carrying out mining operations for winning mica. That, stated the Court, would lead to an unreasonable result which would not in any way subserve the object of the Act. Therefore, the Court was of the view that while before granting permission to start mining operations on a virgin area section 2 of the Act had to be complied with, it was not necessary to seek the prior approval of the Central Government for purposes of carrying out the mining operations on a forest area which was broken up or cleared before the commencement of the Act.

13. AIR 1985 SC 814. 
Distinguishing the above case and the ruling from the present one, the Court stated that in the Ambica Quarries case the operation of the 1980 Act had been given full effect. The Act, the Court stated, was enacted in recognition of the awareness of the fact that deforestation and ecological imbalances should be prevented. The Court added: "that was the primary purpose writ large in the Act of 1980. Therefore, the concept that power couples with the duty enjoined upon the respondents to renew the lease stands eroded by the mandate of the legislation as manifested in the 1980 Act, given the facts and circumstances of this case. The primary duty was to the community and that duty took precedence in our view in these cases. The obligation to the society must predominate over the obligation to the individuals". ${ }^{14}$ In distinguishing Ambica Quarries from Banshi Ram Modi the Court stated that the appellant in the former was asking for the renewal of the quarrying leases, which would lead to further deforestation. From that view of the matter and the facts and circumstances of the case, the Court felt that the rationale of the latter case cannot be made applicable to support the appellant's demands in the present case because the facts were entirely different.

In Kinkri Devi v. The State of Himachal Pradesh, ${ }^{15}$ the Himachal Pradesh High Court was moved under a social action litigation by a group of petitioners who depended upon an article published in the 6 April 1987 edition of Indian Express under the heading "Progress or People's Nightmare". The article highlighted the damage caused to the Shivalik hills in the Sirmaur district which were being "ruthlessly blasted for extracting limestone" and the danger and hazards faced by the inhabitants and the disturbance to the environment and ecology as a consequence thereof. The article was based on an investigative exercise made by a team of journalists who visited a number of mining sites in the district. The Court issued notices to the concerned officials and gave direction to the said officials to make an on-the-spot verification of the allegations contained in the Indian Express article. What emerged out of the investigations conducted by the various officials was very interesting.

The Court noted that a perusal and consideration of the material placed at its disposal by the various officials of the Government presented "a curious picture". The affidavit of the Deputy Commissioner and the reports of four senior officers of the State Government revealed the contents of the petition as well as of the newspaper article and the apprehensions expressed therein, with respect to the danger to the hilly tracks of the Sirmaur district and to its environment, etc. and the well-being of

14. AIR 1987 SC 1073, at 1076.

15. AIR 1988 Himachal Pradesh 4. 
the inhabitants because of the quarrying of the limestone in the area in an unscientific and uncontrolled manner, were true to a large extent. However, the affidavit filed on behalf of the State of Himachal Pradesh and those on behalf of the third respondent, i.e. the Conservator of Forests and Wildlife, Shimla, presented a totally different picture. The Conservator of Forests had refuted every allegation made in the petition concerning the hazards resulting from the mining operations undertaken by him. The first respondent, i.e. the Conservator of Forests, Sirmaur district at Nahan, while reluctantly admitting that the mining operations caused a disturbance to the environment, made a statement to the Court that, with a view to protecting the environment and checking reckless or indiscriminate mining operations in the area, the Government had taken the decision not to entertain any mining lease application received after 5 December 1986 and had decided to undertake a detailed study as to the quality and quantity of the mineral deposits, the geological formations, physiography of the area, etc. The picture presented was, noted the Court, that all was well in the State of Denmark. The Court could not help observing that the stand of the State Government was "wholly irreconcilable with the versions of its own officers of rank in charge of the concerned fields of activity and that it is really difficult to appreciate such inconsistency of approaches and that upon the most charitable view being taken, it is capable of being explained only on the basis of a total lack of communication at different levels and organs of the Government machinery". 16

After citing the Supreme Court directions and judgements in the Rural Litigation and Entitlement Kendra case, the Court held that the mining operations in the area had led to the cutting down of the forests, digging of the limestone and allowing the waste to roll down or carried down by rain water to the lower levels which had affected the villages as also the agricultural lands located below the hills. The Court further observed that the activity had led to blocking the naturally formed streams; that the blasting had disturbed the natural quiet, had shaken the soil, had loosened the rocky structures and had disturbed the entire ecology of the area. For removing the limestone quarried from the mines, roads had been laid and for that purpose the hills had been interfered with and traffic hazards for the local population had resulted both for animals and men. Given these facts, the Court, on the authorily of the Rural Litigation and Entitlement Kendra case, had no difficulty in ordering the closure of the mining operations concerned.

16. Ibid, p. 6 . 
After the citation of Articles 48(a) and 51(a)-(g) of the Constitution, by which a duty had been created for every citizen of India to protect and improve the natural environment, the Court stated that although the two provisions were under the Directive Principles of State Policy, they constituted a pointer to the State and created a constitutional duty for all citizens not only to protect but also to improve the environment and preserve the safeguards of the forests, the flora and fauna, the rivers and lakes and all other water resources of the country. The Court added: "The neglect and failure to abide by the pointer or to perform the duty is nothing short of the betrayal of the fundamental law which the State and indeed every Indian, high or low, is bound to uphold and maintain". The Court pointed out that exploitation of mineral resources in the interest of industrial growth of the country was necessary, but such mines should so work as not to disturb the ecology and not to affect the livelihood and the living conditions of a very large number of the people. The advantage gained by working the mines for industrial growth and national development in a manner which may seriously prejudice the interests of a large number of human beings and disturb the ecological balance, might very much be outweighed by the serious consequences which were likely to follow. The Court pointed out that industrial development was necessary for the economic growth of the country in the larger interest of the nation. If, however, industrial growth was sought to be achieved by a haphazard and reckless working of the mines resulting in the loss of life, property, basic amenities, like supply of water, and creation of ecological imbalance, there might ultimately be no real economic growth and no real prosperity. It was necessary to strike a proper balance. If the operations like the ones under consideration had resulted in a far-reaching and lasting adverse impact on the natural wealth and resources of the country, then the judiciary, affirmed the Court, cannot remain a silent spectator.

After the above strong statement, the Court ordered the setting up of a committee under the chairmanship of the Chief Secretary and consisting of the Secretaries in the departments of industry, public affairs, forest, agriculture, science and technology, and environment. The committee were to examine, inter alia, the question whether the grant of mining leases in respect of limestone in Tehsil Paonta Sahib, Renuka and Rajgarh, as per the particulars furnished in the annexe to the affidavit and filed by the Deputy Commissioner, Sirmaur, and more particularly the grant of such leases in or around the village Sangra, Tehsil, Renuka, District Sermaur was in accordance with the relevant statutory provisions, and whether the need for maintaining a proper balance between the tapping of the mineral resources for the development and the industrial growth on one hand, and the ecology, environment etc. on the other, had been 
kept in view while making such grants, and whether those mines were being scientifically operated or worked in an erratic and uncontrolled manner, posing present and potential danger to the soil, the agriculture, the forests, the water resources and the water supply schemes, the rivers, streams, the flora and fauna, the ecology, the environment and life and living conditions of the people and their property. The Court directed the committee to hold such enquiry as it thought fit for the purposes of arriving at a considered opinion in regard to tlic above matters, taking such assistance of experts as was necessary. Obviously, the earlier affidavits filed by the various officers of the State Government had not satisfied the Court and it felt obliged to establish a high-level committee of its own.

The interplay between environment and development came to the fore in Banwasi Sewa Ashram v. The State of Uttar Pradesh. ${ }^{17}$ The case presented for resolution a tangle of claims on a reserved forest declared so under section 20 of the Indian Forest Act 1927 by the State of Uttar Pradesh. The area contained 433 villages lying south of the Kaimur Range of the Mirzaput district. Of those, 299 were in Dughi tehsil and the remaining 134 in Robersganj tehsil. The area involved was 923,293 acres, out of which, in respect of $58,937.42$ acres, notification under section 20 of the said Act had been made, declaring the same as reserved forest, and in respect of 789,086 acres notification under section 4 of the Act had been made. The Adivasis (tribals) in these forests had been in occupation of roughly 782,000 acres. There were two sets of claims and challenges to the proclamation of reserved forest made by the State Government in question; the first by some of the Adivasis who had used the forest area as their habitat. The Court noted that the Adivasis had raised several villages within the two tehsils and for generations had been using the jungles around for collecting the requirements for their livelihood - fruits, vegetables, fodder, flowers, timber, animals, by way of sport and fuel wood. When a part of the jungle became reserved forest and proceedings under the Act were initiated, the forest officers started interfering with their operations in those areas. Criminal cases for encroachment as also other forest offences were registered and a systematic attempt was made against the Adivasis to obstruct free movement. Steps were also taken to throw the Adivasis out of the area.

The State Government had decided in the meanwhile that a super thermal plant of the National Thermal Power Corporation Ltd. (for short, NTPC) would be located in part of the same area and acquisition proceedings for that purpose had been initiated. The NTPC was therefore a party before the Court.

17. (1969) 4 Supreme Court Cases 753. 
The Court had to strike a balance between the needs of the Adivasis and the development goals of the State. The Court did that by noting first that forests were a much wanted national asset and that depletion of forests had taken place alarmingly and the ecology had been disturbed. It further noted that the climate had undergone change and drains had become scanty; that the long-term adverse effects on national economy as also on the living process was self-evident. At the same time, pointed out the Court, "[w]e cannot lose sight of the fact that for industrial growth and also for provision of improved living facilities there is a great demand in this country for energy such as electricity. In fact, for quite some time the entire country in general and specific parts thereof in particular have suffered tremendous setback in industrial activity for want of energy. A scheme to generate electricity therefore is equally of national importance and cannot be deferred". ${ }^{18}$

The Court therefore adopted an elaborate mechanism and appointed a structure of committees and administrative machinery aimed at the investigation of the claims of the Adivasis with a view to satisfying their needs on part of the reserved land and allowing the NTPC to proceed with their scheme on the rest of the land which was sought to be acquired by the State. The administrative machinery consisted of two sets of officials of different levels, the first was empowered to investigate the claims of the Adivasis and consisted of revenue officials. The second rung comprised judicial officials of the rank of the Additional District Judge to be appointed by the Chief Justice of Uttar Pradesh. The forest settlement officer's finding on the maintainability of the claims of the Adivasis was to be placed for approval or otherwise of the judicial officers of the areas concerned. The Court also directed that legal aid shall be provided to the claimants and persons seeking to raise claims and for facilitating the obtaining of requisite information for lodging of claims. The Government was bound, so also the NTPC, to honour the decision of the forest settlement officers and also to provide facilities to land oustees. The Court appointed a Board of Commissioners to supervise the operations and oversee the implementation of the directions given before the Board of Commissioners.

The requirement of prior approval of the Central Government under section 2 of the Forest Conservation Act came up for a very close scrutiny in Anupama Minerals v. The Union of India. ${ }^{19}$ The case concerned the land in survey number 7 of the Gandepalli village which was situated in the reserved forest bearing the same name. The said land was found to con-

18. Ibid, pp. 756-757.

19. AIR 1986 Andhra Pradesh 225. 
tain limestone which is a minor mineral. The grant of leases with respect to minor minerals is governed by the Andhra Pradesh Minor Minerals Concession Rules, 1966. The appropriate authority to grant the mining leases under these rules is the Assistant or the Deputy Director as the case may be. The competent authority granted four leases in the area concerned to different individuals. A proviso to the A.P. Minor Minerals Concession Rules stated that leases in respect of a reserved forest land can be granted only after consultation with the divisional or the district forest office concerned.

Among the many issues contended before the Andhra Pradesh High Court was the one as to who was to seek the prior approval of the Central Government for permission under section 2 of the Forest Act. According to a circular letter sent by an Under-Secretary to the Govermment of India, Ministry of Agriculture in New Delhi, addressed to the Forest Secretaries of all States and Union territories, the individual departments of the State Governments were directed not to address the Central Government for approval and that it was the administrative responsibility of the Forest Departments which was the real custodian and owner of the forests in each State to correspond with the Central Government regarding transfer of forest areas, etc.

The Andhra Pradesh High Court held that the officer concemed had not "correctly appreciated the import of the procedure prescribed by the rules". The Court stated that the directive that prior approval of the Central Government should be sought for only by the Forest Departments was not the requirement by the rules. On the other hand, the Court added, Rule 4 spoke of permission being sought for by the State Government or other authority. Vesting the Forest Departments of the States with such a power would be, according to the A.P. High Court, "practically conferring a power of veto on the Forest Departments of the States in such matters." The Court further noted that the decision to approve or disapprove of requests made lay with the Central Government and such a power would not be transferred to the Forest Departments of the States because under the procedure suggested by the above mentioned officer of the Government of India all other departments of State would have to route the request of prior approval through the Department of Forests, and the Department of Forests under that procedure would gain a monopoly of such request-making.

Another important point that came up for consideration before the A.P. High Court was as to whether the Forest Department had a duty to forward a request for dereservation or otherwise under section 2 of the Forest Act in all cases. The Court noted that the Deputy Director of Mines and Geology had sought the prior approval of the Central Government; 
such a contingency would arise only if and when the authority was satisfied that the application for grant of renewal of lease was in order and in conformity with the State Government rules and also only if he was of the opinion that the request ought to be granted. It was only when the officer concerned was of the opinion that an occasion had arisen for him to seek a prior approval of the Central Government that he ought to forward the application. If the application was not in order or, for some other weighty reasons of the State, the officer concerned was not convinced that there was a fit case for dereservation, etc., then the prior approval of the Central Government would only moot.

Adivasis are not the sole claimants for the use and fruits of the forests. Kaniram v. State of Madhya Pradesh offers a situation in which the objective of conservation of forests came into clash with the livelihood of a particular group of people who are not necessarily Adivasis. Petitioners in this case were residents of the District Mandsaur in the State of Madhya Pradesh, who had carried on the business of breeding and selling camels, and which business, according to the petitioners, was their only source of livelihood. The petitioners had been granted licenses for grazing their camels in the forest in accordance with the Madya Pradesh Grazing Rules, 1979 , framed by the State Government in exercise of the power conferred by section 76 of the Indian Forest Act of 1927. In 1982, the applications of the petitioners for grant of grazing licences were, however, not accepted by the Government on the ground that there was an order issued by the State Government discontinuing the practice of granting grazing licences for that year.

The granting of licences for grazing purposes was covered by the rules entitled Madhya Pradesh Grazing Rates and Rules, 1979. Under these rules the State Government was empowered to grant permits for grazing at commercial rates. The rules prohibited grazing in reserved forests. The Court noted that the petitioners were not seeking the grant of licences for grazing their camel in the reserved forests. It was also admitted that the divisional forest officer had not declared the District of Mandsaur as closed for grazing under rule 4 of the aforesaid Rules. The Court also noted that the State Government had notified, in the Official Gazette of 28 August 1979, the rates for camel grazing. On the basis of a reading of the relevant rules, the Court found that the State Government did not have the power to impose a total ban on grant of licences for grazing by camels.

The plea taken by the State Government was that the granting of licences for grazing was a discretionary matter and that the applicants were not entitled to a concession of that nature as a matter of right. It was also pointed out that the grazing by camels had led to extensive destruc- 
tion of trees. The Court, citing the Supreme Court decisions in Ramana Dayaram Shetty v. International Airport Authority of India ${ }^{20}$ and Messrs Kasturi Lal, Lakshmi Reddy v. State of Jammu and Kashmir ${ }^{21}$ ruled that it was well-settled that every activity of the Government had a public element in it and it must therefore be informed with reason and guided by public interest. It was no longer open to the State Government, the Court ruled further, to contend that it could exercise its discretionary powers in any manner it liked. The Court saw no evidence whatsoever that showed that the action of the State Government was based on sound reason and was not arbitrary and was in public interest. Therefore, the Court dismissed the State Government's contention on that score.

Deforestation in the country had led to some State Governments, under the inspiration of the Forests Conservation Act of 1980, to adopt a policy imposing a ban on cutting and felling of trees in the forest. The U.P. Government had declared on 21 October 1981 that henceforth no private individual would be allowed to cut and fell trees in the forest and that the task was to be done by the U.P. Forest Corporation only. The new policy led some enthusiastic forest officers to overreact to private felling even under licence. In Daya Shankar Singh v. The Conservator of Forest (Southern Zone), U.P, ${ }^{22}$ the Uttar Pradesh High Court was confronted with a case in which petitioners were forest contractors in the District of Mirzapur. They had purchased a number of forest lots in the Dudhi Forest division in the District of Mirzapur for cutting and removal of trees during 1980-81. The forest authorities entered into an agreement with the petitioners which stipulated that the petitioners would complete the cutting of trees by 31 March 1981 . The petitioners had made the necessary deposits, but could not cut or remove the trees within this stipulated time. They applied for extension of period to enable them to cut and remove the trees on the ground that there was acute shortage of labour for the period in question. They had paid the contract money of Rs. 4.2 million.

On a reading of the standing orders governing the issue of licences and revoking of the same, the Court held that the Conservator of Forest, who was a public authority acting on behalf of the Government, was required to act in a reasonable manner while exercising his powers under the standing orders. In matters relating to granting of extension of periods of licence, he could not act arbitrarily at his own will, like a private individual. Instead, he must act in conformity with the Constitution and the principles laid down in the standing orders in a manner which may withstand

20. AIR 1979 SC 1628.

21. AIR 1980 SC 1992.

22. AIR 1984 Allahabad 188. 
the test of reasonableness. Any departure from the principle of reason, held the Court, or the principle of equality would vitiate the order.

The Court found the facts pleaded, especially relating to the acute shortage of labour in the area, to be true. And the grounds on which the Conservator of Forest had refused extension, namely, that under the new U.P. Forest Policy no private individual was allowed to cut and remove forest trees, was held by the Court to be a prospective application of a policy unwarranted under the existing legislation of the State.

The U.P. High Court was quite considerate however, in the case of the State of U.P. v. The Additional District Sessions Judge, Varanasi ${ }^{23}$ in which the notification required under sections 3 and 4 of the Forest Act (as amended in U.P.) was alleged to be vitiated by vagueness. The Court held that the area in question was huge and that the specifications made of the boundaries with reference to pillars was quite clear. The Court held that it was manifest that the specification given of the area in acres and also the boundaries was vague, but it was practically impossible to have specified the numerous plot numbers and there was no such requirement under the statute.

The objective of conservation of forest, which is the primary goall of the Forest Conservation Act, 1980, could and has run into problems when confronted with another salutary goal of State policy, namely distribution of land to the landless. In the State of Kerala v. Musa Haji case ${ }^{24}$ the Kerala High Court had before it the Kerala Private Forests (Vesting and Assignment) Act of 1971 and the Madras Preservation of Private Forests Act of 1949 for interpretation and reconciliation. The first Act had an enabling provision for the vesting of private forests in the State Government and for assignment thereof to agriculturists and agricultural labourers for cultivation, as in the opinion of the legislature, all private forests in Kerala were agricultural lands. Section 10 of the said Act envisaged the vested forest's distribution among agricultural labourers, Scheduled Castes and Scheduled Tribes, unemployed young persons and others interested in taking up agriculture as their means of livelihood.

The Madras Preservation of Private Forests Act, 1949 (MPPF Act, for short) sought to prevent indiscriminate destruction of private forests and interference with customary and prescriptive rights therein. The Act applied to private forests of the Malabar and South Kanara Districts of the erstwhile Madras State. The key provision in that Act was section 3 which prohibited alienation of any part of the former and cutting of trees or the doing of any act that was likely to denude or diminish the utility of the for-

23. AIR 1984 Allahabad 1360.

24. AIR 1984 Kerala 149. 
est, except with the previous permission of the District Collector. There were thus two Acts or legislative measures that sought to protect forests on the one hand and promote the interest of the weaker sections of the people, on the other.

In Kerala v. Gwatiar Jain ${ }^{25}$, the Supreme Court had an occasion to examine the Kerala Vesting Act and had taken the view that the said Act was a legislative measure which could be construed as a scheme of agrarian reform designed to take over agricultural lands comprised in private forest and for the settlement of the poorer classes of the rural population on those lands for promotion of agriculture, etc. The Kerala Government had also adopted a Land Reforms Act in 1964, placing the ceiling on the land that could be possessed by private individuals or families, and had by that Act taken over the excess land on payment of compensation for distribution amongst the landless agricultural labourers, etc.

The Musa Haji case revolved around what could be considered as private forests and whether teak plantations were exempted under section $B$ of the Act. The Court refused to classify teak cultivation under the exemption provisions of the Act insofar as teak could not be considered as a fruit-bearing tree or an agricultural crop. The detailed exposé on the interpretation of the Act and its exemptions is not relevant to the present purposes. What is noteworthy is the attitude of the Kerala Government which was prima facie in conflict with the requirements of the conservation of forests. The Court had, as the Supreme Court also in the Gwaliar Ryan case had done, construed the developmental aspirations of the State as consistent with the conservation requirements of the forests.

\section{CASES UNDER THE WILD LIFE PROTECTION ACT}

The Wild Life Protection Act, 1972, has received a heartening response from the Indian judiciary, at least in terms of its purposes and background. In Nellikka Achuthan v. Deshabhimani Printing and Publishing House Ltd, ${ }^{26}$ the Kerala High Court noted that the Act had brought about "massive changes" and that it constituted "the projection of the Parliamentary will for the protection of the wild life, in the background of the well-known Stockholm Declaration of 1970 (sic) wherein the then Prime Minister of India was a principal participant". ${ }^{27}$ In State of Bihar v. Murad

25. AIR 1973 SC 2734.

26. AIR 1986 Kerala 41.

27. Ibid, at 44 . 
Ali Khan, ${ }^{28}$ the Supreme Court of India demonstrated an erudition that went beyond a mere familiarity with the Stockholm Declaration:

\begin{abstract}
"In policy and object the Wild Life laws have a long history and are the result of an increasing awareness of the compelling need to restore the serious ecological imbalances introduced by the depredations inflicted on nature by man. The state to which the ecological imbalances and the consequent environmental damage have reached is so alarming that unless immediate, determined and effective steps were taken, the damage might become irreversible. The preservation of the fauna and flora, some species of which are getting extinct at an alarming rate, has been a great and urgent necessity for the survival of humanity and these laws reflect a last-ditch battle for the restoration, in part at least, (of) a grave situation emerging from a long history of callous insensitiveness to the enormity of the risks to mankind that go with the deterioration of environment. The tragedy of the predicament of the civilized man is that every source from which man has increased his power on earth has been used to diminish the prospects of his successors. All his progress is being made at the expense of damage to the environment which he cannot repair and cannot foresee. In his foreword to International Wild Life Law: H.R.H. Prince Philip, the Duck (sic) of Edinburgh said..." 29
\end{abstract}

Citing two more passages from the same foreword, the Supreme Court proceeded to quote the World Charter of Nature to emphasize the dependence of mankind on the natural systems, and a decree issued by the Emperor Ashoka in the third century B.C. that demonstrated the great ruler's concern for wild animals.

The Courts have had, however, considerable difficulty in translating into action this profound appreciation of the purport of the Act. The provisions of the Act, interfaced with the other laws of the land, produced the principal complications. But the Courts, on occasions, have had the unenviable task of choosing between the rights of human beings and those of the wild animals.

The Act itself seeks to resolve this dilemma, in a way. Section 218 of the Act, for instance, empowers the Government to declare an area as a "sanctuary" in order to protect one or more of the species of wild life. But the exercise of this power is subjected to certain conditions. The same section requires that such a declaration is to be made by a notification which, according to section 22, needs to be published in the Official Gazette. Section 19, substantially, enjoins the Collector to inquire into, and determine the existence, nature and extent of the rights of any person in or over the land comprised within the limits of the sanctuary. Sec-

28. AIR 1989 SC 1.

29. Ibid, at 34 . 
tion 21 and 22 oblige the Collector to issue the proclamation only after giving the notification the widest publicity in the language of the region, and after settling the claims preferred by the affected people.

If the stated conditions are met, the proclamation of a sanctuary will be valid. There is thus an apparent preference for the rights of the wild animals over those of human beings. But it is more apparent than real. For, it is the very existence of a certain species threatened with extinction that is sought to be protected, and the property, loss and displacement costs of the people are compensated. The task of the Guwahati Court in Jaladhar Chakma v. The Deputy Commissioner, Aizawl ${ }^{30}$ was easy in that the declaration of a sanctuary was found to be in complete violation of the procedure and substance of all the above sections of the Act and was consequently struck down, but the concern for the petitioner's "hearths and home" and for the property rights over the "cultivable lands" comes out clearly. People, subliminally, appear to have had an edge over wild life in this case.

In the other two cases, cited above, namely Nellikka Achuthan and Murad Ali Khan, however, the Kerala High Court and the Supreme Court showed a touching concern for India's best-known and precious animal, i.e., the elephant. In the former case, the plaintiff was charged with the shooting down of a wild elephant that had strayed into his estate, and having removed its tusks. There was considerable argument, on the plaintiff's behalf, whether a wild elephant, when shot down on a private estate, would be property belonging to the Government or the plaintiff. The question had an important bearing on the plaintiff's defamation suit brought against the defendant newspaper which had reported the incident as "a case of theft".

The Kerala High Court decided the issue not by reference to what it called "the principles of abstract property law", but by reference to the lex specialis: the Madras Wild Elephants Act, 1878, the Elephants Preservation Act 1879 and the Wild Life (Protection) Act, 1972. Basing itself on the last enactment, the Court noted the definition of "wild animal" as one found wild in nature and included in the five schedules of the Act. The Court found that the elephant was included in Schedule II.

The Court stated that killing the elephant was prohibited by the Act, except in self-defence, and that under section 39 every wild animal hunted or killed in violation of the provisions of the Act shall be the property of the State Government. Disposal of such animal and removal of its tusks constituted theft under the Act. The Court found that the plaintiff

30. AIR 1983 Guwahati 18, at 20. 
had "feigned innocence", but that the tusks were removed with "a dishonest intention" to appropriate to himself. 